\title{
Heterotrophic Bacterial Flora Associated with European Eel Anguilla anguilla Reared in Freshwater
}

\author{
Consuelo Esteve*1 and Esperanza Garay*1,2 \\ (Received January 7, 1990)
}

\begin{abstract}
The heterotrophic bacterial microflora of European eel reared in freshwater and its surrounding aqueous environment is reported. Quality of eel culture water is also discussed with respect to its physicochemical and bacteriological characteristics. The presence of bacterial species pathogenic for eel and its serological classification was investigated in fishery water and eels. Overall 675 isolates from fishery water and healthy or diseased were eel identified at genus level. Pseudomonas was the most frequently encountered genus. Moraxella $\mathrm{sp}$. and Acinetobacter sp. were abundant in fishery water, and Aeromonas sp. in elver and internal organs of silver eel. Plesiomonas sp., Escherichia sp., Enterobacter sp., Serratia sp., Citrobacter sp., and Streptococcus sp. were minority genera that were only recovered from eel. The species Aeromonas hydrophila, A. sobria, and Alteromonas putrefaciens were mostly isolated from diseased eel whereas other potential fish pathogens such as $P$. fluorescens, $V$. anguillarum, and Plesiomonas shigelloides were generally observed in fishery water or healthy eel. Following the typing scheme of Guinée and Jensen, most of the isolates of $A$. hydrophila from diseased European eels, as well as the strain $A$. hydrophila Y-62 pathogenic for Japanese eel, belonged to 019 serogroup. A relationship between origin and serogroup for $A$. sobria was not observed. None Vibrio anguillarum isolates agglutinated with $\mathrm{O} 1$ and $\mathrm{O} 2$ antisera of Sorensen and Larsen.
\end{abstract}

Characterization of the bacterial communities related to eel rearing systems can be useful to understand the onset of infectious diseases, since this microflora may include opportunistic pathogens with an active role in the development of epizootics. On the other hand, the number of epizootic outbreaks produced by obligate pathogens of eel such as Pseudomonas anguilliseptica and Vibrio vulnificus biotype 2 so far is limited. ${ }^{-4)}$

Aeromonas hydrophila is one of the most important species potentially pathogenic for fish. This bacterium is frequently isolated from aquatic ecosystems, and it is considered to have worldwide distribution. Many reports have recognized it as pathogen from a wide variety of freshwater fish species. Among them $\mathrm{Kou}^{5)}$ in Taiwan, Rickards ${ }^{(2)}$ in Japan, Levanon et al. ${ }^{(7)}$ in Israel, and Mellergaard and Dalsgaard ${ }^{3\rangle}$ in Denmark reported on Aeromonas hydrophila as a causative agent of epizootic outbreaks in eels. Recent studies suggest that motile Aeromonas strains can be separated serologically and antigenically in various groups. $\left.{ }^{\theta}, 10\right)$ These seroepidemiolo- gical results could be crucial for planning effective vaccination programmes. Nevertheless, descriptions of the normal bacterial flora of fish and its artificial rearing environment are almost limited to those carried out with salmonids. ${ }^{11,12)}$

We have carried out a study of the heterotrophic bacterial flora of eel culture water, elvers, and silver eels at an eel breeding plant near Valencia (Spain) over a one year period. We have also studied the bacterial species recovered from epizootic outbreaks and their serological classification. The physicochemical parameters of the eel culture water were investigated in order to evaluate its quality to rear eels.

\section{Material and Methods}

\section{European Eel Farm}

The eel farm is located in Valencia, on the Mediterranean coast of Spain. European eels were stocked at $30 \mathrm{~kg} / \mathrm{m}^{3}$ in concrete tanks of 1.30 to $1.80 \mathrm{~m}$ diameter and $0.70 \mathrm{~m}$ depth supplied with spring freshwater without any system to recirculate or heat the inflowing water.

\footnotetext{
*1 Departamento de Microbiología, Facultad de Ciencias Biológicas, Universidad de Valencia, Burjasot, 46100 Valencia, Spain.

*2 To whom any correspondence should be addressed.
} 


\section{Sample Collection}

Samples of eel culture water (inflow and tank) and eels (elvers and silver eels) were taken at the mentioned eel farm from April 1987 until March 1988. Inflowing and tank water were collected $5 \mathrm{~cm}$ below the surface in sterile $500 \mathrm{~m} l$ glass bottles. Fifty elvers (average weight $0.3 \mathrm{~g}$ ) were chosen from a random sample from each tank studied. These were washed by vigorous agitation in sterile saline solution (SS) $(0.9 \% \mathrm{w} / \mathrm{v} \mathrm{NaCl})$ to remove the surface microflora, and the elvers were then homogenized in sterile SS. Samples of elver homogenate were used for bacteriological analysis. Three silver eels (weight 7-72 g) were randomly choosen from each tank studied. Samples of kidney, liver, and gills from each silver eel were used for bacteriological analysis.

\section{Physico-chemical Paramenters of Water}

Salinity was measured in situ using a salinometer YSI model 33SCT. Dissolved oxygen and water temperature were determined in situ using dissolved oxygen + temperature meter (Syland).

Hydrogen ion activity was measured in situ using a pH meter Orion SA250. Biological oxygen demand $\left(\mathrm{BOD}_{5}\right.$ ) was determined in the laboratory with an Orion 97-08 oxygen electrode. ${ }^{13)}$ Determinations of nitrate and nitrite ions were performed by Griess's method, ammonium ion was measured with an Orion 95-10 ammonium electrode. ${ }^{13)}$

\section{Bacteriological Analysis}

1. Faecal indicator microorganisms: CFU (colony forming unit) of faecal coliforms and enterococci in samples of inflowing and tank waters were determined by membrane filtration culture method. ${ }^{13)}$

2. Viable cell counts and isolation of bacterial strains on non selective media: CFU of heterotrophic mesophilic bacteria in samples of inflowing and tank waters, and elvers homogenate were determined by plate count method ${ }^{13)}$ on tryptone soya agar (TSA) (Oxoid), with incubation at $22^{\circ} \mathrm{C}$ for seven days. Isolation of bacterial strains was made on TSA plates with $>30$ to 300 colonies. $46 \%$ of colonies from inflowing water, $56 \%$ of colonies from tank water, and $71 \%$ of colonies from elver homogenate were picked off and subcultured repeatedly on fresh media until purification was achieved. Samples of gills, liver, and kidney from silver eel were streaked directly on duplicate plates of TSA and brain heart infusion (BHI) (Difco) agar, and incubated as described previously. Three colonies of each morphological type were picked off and purified on TSA plates.

3. Isolation of bacterial strains on selective media: Samples of inflowing and tank waters, elvers homogenate, as well as gills, liver, and kidney from silver eels were streaked on duplicate plates of MacConkey agar (Oxoid) and thiosulphate citrate bile sucrose (TCBS) agar (Oxoid). The plates were incubated at $28^{\circ} \mathrm{C}$ for two days and then three colonies of each morphological type were picked off and streaked in TSA plates.

\section{Bacterial Identification}

Bacterial isolates were identified to genus level using Bergey's Manual of Systematic Bacteriology (Vols. 1 and 2). The routine identification included the following tests: colony pigmentation,

Table 1. Physicochemical parameters of inflowing and tank waters

\begin{tabular}{|c|c|c|c|c|c|c|c|c|c|}
\hline $\begin{array}{c}\text { Date/Fish } \\
\text { holding tank }\end{array}$ & $\begin{array}{l}\text { Water } \\
\text { sample }\end{array}$ & $\begin{array}{c}\text { Temperature } \\
\left({ }^{\circ} \mathrm{C}\right)\end{array}$ & $\begin{array}{c}\text { Dissolved } \\
\text { oxygen } \\
\text { (ppm) }\end{array}$ & $\mathrm{pH}$ & $\begin{array}{c}\text { Salinity } \\
(\%)\end{array}$ & $\underset{\left(\mathrm{mg} / / \mathrm{O}_{2}\right)}{\mathrm{BOD}_{5}}$ & $\begin{array}{l}\mathrm{NO}_{3}^{-} \\
(\mathrm{ppm})\end{array}$ & $\begin{array}{l}\mathrm{NO}_{2}^{-} \\
(\mathrm{ppm}) \\
\times 10^{3}\end{array}$ & $\begin{array}{l}\mathrm{NH}_{4}^{+} \\
(\mathrm{ppm}) \\
\times 10^{3}\end{array}$ \\
\hline \multicolumn{10}{|l|}{ April, 87} \\
\hline & Inflow & 19.0 & 7.1 & 7.3 & 0.1 & $\mathrm{ND}^{*}$ & 74.8 & 3 & 18 \\
\hline $\mathrm{T} 1$ & Tank & 19.0 & 6.7 & 7.2 & 0.5 & ND & 80.2 & 208 & 18 \\
\hline \multicolumn{10}{|l|}{ August, 87} \\
\hline & Inflow & 19.7 & 5.3 & 7.1 & 0.1 & 1.7 & 50.0 & 30 & 81 \\
\hline $\mathrm{T} 4$ & Tank & 20.9 & 8.6 & 7.4 & 0.5 & 3.2 & 45.0 & 180 & 3 \\
\hline \multicolumn{10}{|l|}{ December, 87} \\
\hline & Inflow & 17.0 & ND & 7.5 & 0.1 & 1.7 & 45.9 & 28 & 2 \\
\hline $\mathrm{T} 1$ & Tank & 17.0 & ND & 7.5 & 0.1 & 1.7 & 45.9 & 9 & 162 \\
\hline \multicolumn{10}{|l|}{ February, 88} \\
\hline & Inflow & 17.0 & 6.7 & 7.4 & 0.1 & 1.0 & 29.1 & 9 & 19 \\
\hline $\mathrm{T} 1$ & Tank & 16.6 & 5.1 & 7.2 & 0.1 & 2.0 & 31.0 & 93 & 178 \\
\hline
\end{tabular}

\footnotetext{
* Not determined.
} 
motility, gram reaction, oxidase, $\mathrm{O} / \mathrm{F}$ metabolism, catalase, nitrate reduction, gelatin liquefaction, indole production, and $\mathrm{SH}_{2}$ production. API system $20 \mathrm{E}$ was used for identification of enterobacteria to the species level. Additional tests used to identify Vibrio, Plesiomonas, and Aeromonas species were based on the schemes of Poppof ${ }^{14)}$ and Lee \& Donovan:15) O/129 sensitivity $(150 \mu \mathrm{g})$, gas production from glucose, Moeller's decarboxylases for arginine, lysine, and ornithine, growth in $0 \%$ and $6 \% \mathrm{NaCl}(\mathrm{w} / \mathrm{v})$, acid production from arabinose, salicin, and arbutin, Voges-Proskauer, and hydrolysis of esculin. Fluorescent Pseudomonas species were identified using the tests reported by Palleroni: ${ }^{16)}$ Pyoverdin production, Thornley's decarboxylase for arginine, nitrite reduction, DNase production, and growth at $42^{\circ} \mathrm{C}$.

\section{Serology}

Slide agglutination method was used. Twentytwo isolates of $P$. fluorescens (seventeen from eel and five from tank water) and seven isolates of Pseudomonas sp. from fish were serologically tested with the antiserum made against the Japanese strain of $P$. fluorescens O3L (Dr. T. P. Nieto, Spain). Fifteen isolates of $A$. hydrophila (thirteen from eel and two from tank water), nineteen isolates of $A$. sobria (thirteen from eel and six from water), and six isolates of Aeromonas sp. from tank water were serologically tested with thirty $O$ antisera ${ }^{10}$ ) (Dr. A. M. Guinee, The Netherlands). All Vibrio anguillarum isolates were serologically tested with $\mathrm{O} 1$ and $\mathrm{O} 2$ antisera, ${ }^{17)}$ (Dr. J. L. Larsen, Denmark). Pseudomonas fluorescens 03L (Tilatia nilotica, Dr. $\mathrm{H}$. Motoki, Japan), Vibrio anguillarum NCMB $6^{\mathrm{T}}$ and RV22 (Scophtalmus maximus, Dr. M. L. Lemos, Spain), and Aeromonas hydrophila Y-62 (Anguilla japonica, Dr. T. Aoki, Japan) were used as reference.

\section{Results}

\section{Quality of Eel Culture Water}

Temperature of eel culture water ranged from $17^{\circ} \mathrm{C}$ during autumn and winter, to $21^{\circ} \mathrm{C}$ in summer. The $\mathrm{pH}$ values of inflowing and tank water ranged from 7.1 to 7.5. Biological oxygen demand ranged from 1.04 to $1.70 \mathrm{mg} / l \mathrm{O}_{2}$ for inflowing water, and $1.73-3.15 \mathrm{mg} / l \mathrm{O}_{2}$ for tank water. Levels of nitrate in eel culture water fluctuated between 29.1 and $80.2 \mathrm{mg} / \mathrm{l}$. Levels of nitrite ranged from $10^{-3}$ to $10^{-1} \mathrm{mg} \mathrm{NO}_{2}$ -

Table 2. Bacterial counts in water and elver samples*

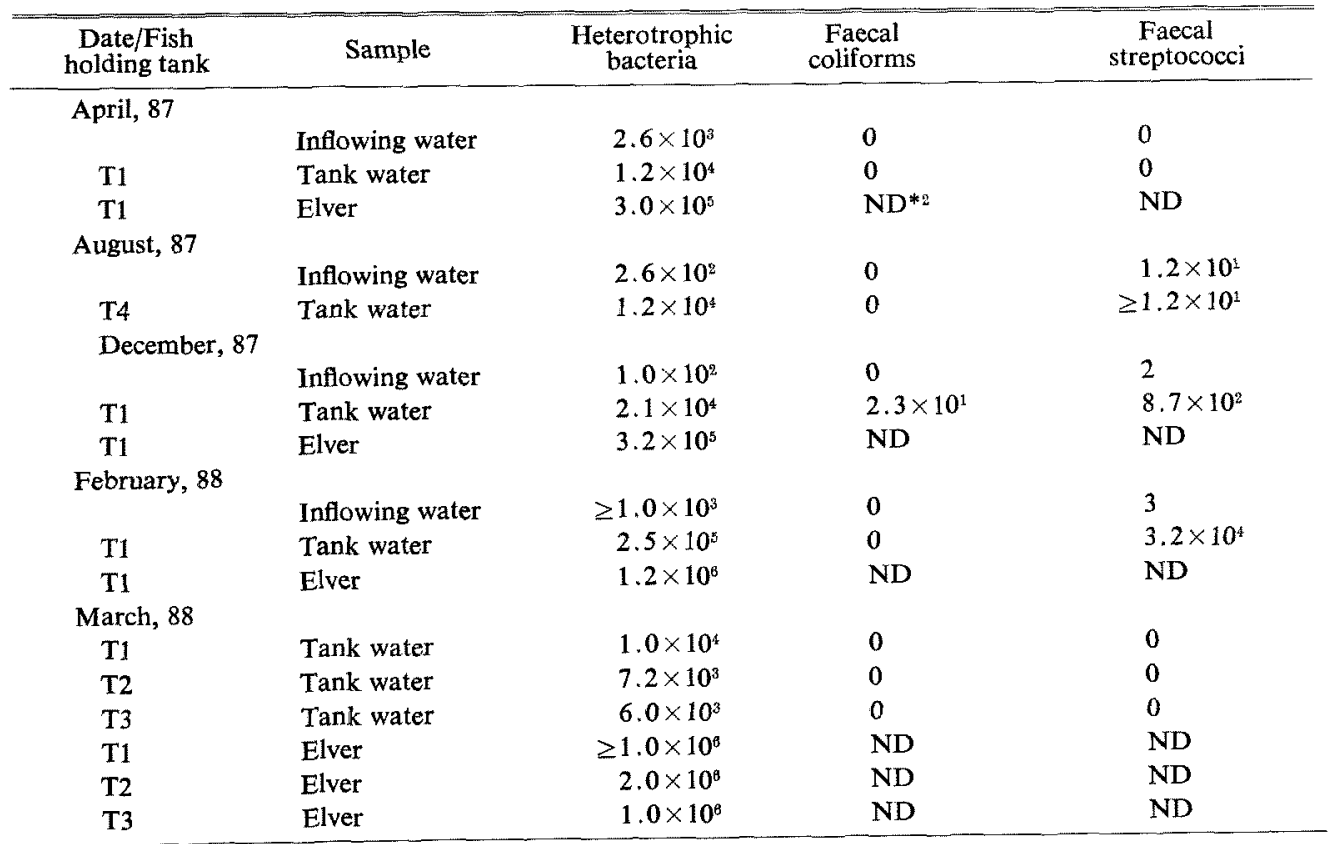

* Water samples, colony forming units per millilitre; elver samples, colony forming units per gram.

*2 Not determined. 
Table 3. Bacteria isolated from water and fish samples on TSA, BHI agar, MacConkey, and TCBS plates throughout the study

\begin{tabular}{|c|c|c|c|c|c|c|c|c|c|c|c|c|c|c|}
\hline $\begin{array}{c}\text { Date/ } \\
\text { Samples*1 }\end{array}$ & $\begin{array}{c}\text { Total } \\
\text { isolates }\end{array}$ & 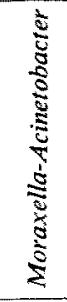 & $\begin{array}{r}8 \\
5 \\
5 \\
8 \\
8 \\
0 \\
0 \\
0\end{array}$ & 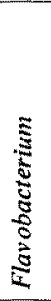 & 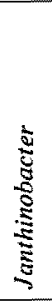 & 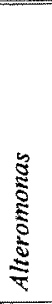 & 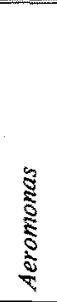 & $\begin{array}{l}.8 \\
5\end{array}$ & 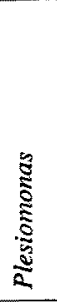 & 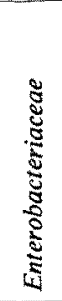 & 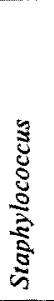 & 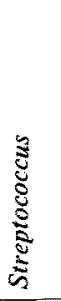 & 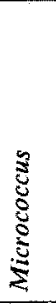 & 密 \\
\hline \multicolumn{15}{|l|}{ April, $87^{* 2}$} \\
\hline IW & 14 & 0 & 4 & 2 & 1 & 0 & 1 & 3 & 0 & 0 & 0 & 0 & 2 & 1 \\
\hline TW & 28 & 2 & 17 & 1 & 0 & 0 & 0 & 0 & 0 & 0 & 1 & 0 & 4 & 3 \\
\hline $\mathrm{HE}$ & 34 & 0 & 3 & 0 & 0 & 0 & 16 & 1 & 0 & 0 & 3 & 0 & 9 & 2 \\
\hline DE & 32 & 0 & 14 & 0 & 0 & 0 & 9 & 1 & 0 & 0 & 0 & 0 & 7 & 1 \\
\hline \multicolumn{15}{|c|}{ August, $87^{* 2}$} \\
\hline TW & 22 & 0 & 12 & 2 & 0 & 0 & 1 & 1 & 0 & 0 & 1 & 0 & 2 & 3 \\
\hline GHSE & 14 & 1 & 10 & 1 & 0 & 0 & 0 & 0 & 0 & 0 & 1 & 0 & 1 & 0 \\
\hline LHSE & 15 & 0 & 0 & 0 & 0 & 0 & 3 & 0 & 0 & 2 & 3 & 5 & 2 & 0 \\
\hline GDSE & 38 & 0 & 16 & 3 & 0 & 3 & 6 & 2 & 0 & 3 & 2 & 0 & 2 & 1 \\
\hline LDSE & 16 & 0 & 6 & 0 & 0 & 1 & 2 & 0 & 0 & 1 & 3 & 1 & 2 & 0 \\
\hline \multicolumn{15}{|c|}{ December, 87} \\
\hline IW & 7 & 1 & 2 & 0 & 0 & 0 & 0 & 0 & 0 & 0 & 0 & 0 & 2 & 2 \\
\hline TW & 63 & 20 & 7 & 9 & 0 & 1 & 8 & 11 & 0 & 2 & 0 & 0 & 3 & 2 \\
\hline $\mathrm{HE}$ & 72 & 2 & 12 & 0 & 0 & 1 & 39 & 5 & 0 & 13 & 0 & 0 & 0 & 0 \\
\hline \multicolumn{15}{|c|}{ January, $88 * 2$} \\
\hline TW & 21 & 0 & 0 & 0 & 0 & 0 & 11 & 10 & 0 & 0 & 0 & 0 & 0 & 0 \\
\hline LDSE & 8 & 0 & 1 & 1 & 0 & 6 & 0 & 0 & 0 & 0 & 0 & 0 & 0 & 0 \\
\hline \multicolumn{15}{|c|}{ February, 88} \\
\hline IW & 10 & 8 & 1 & 0 & 0 & 0 & 0 & 0 & 0 & 0 & 0 & 0 & 0 & 1 \\
\hline TW & 74 & 8 & 55 & 2 & 0 & 1 & 8 & 0 & 0 & 0 & 0 & 0 & 0 & 0 \\
\hline $\mathrm{HE}$ & 74 & 8 & 47 & 0 & 0 & 2 & 7 & 1 & 1 & 8 & 0 & 0 & 0 & 0 \\
\hline GHSE & 16 & 1 & 9 & 0 & 0 & 0 & 6 & 0 & 0 & 0 & 0 & 0 & 0 & 0 \\
\hline LHSE & 56 & 2 & 41 & 1 & 0 & 1 & 6 & 0 & 2 & 3 & 0 & 0 & 0 & 0 \\
\hline \multicolumn{15}{|c|}{ March, $88^{* 2}$} \\
\hline TW & 27 & 2 & 2 & 0 & 0 & 2 & 6 & 9 & 0 & 3 & 1 & 0 & 1 & 1 \\
\hline$D E$ & 29 & 0 & 9 & 0 & 0 & 0 & 15 & 0 & 0 & 3 & 1 & 0 & 0 & 1 \\
\hline
\end{tabular}

$\mathrm{N} / l$ for inflowing and tank waters (Table 1$)$. The amounts of viable heterotrophic bacteria, faecal coliforms, and enterococci in eel culture water are summarized in Table 2. Viable counts of heterotrophic bacteria of inflowing water $\left(10^{2}\right.$ $10^{3}$ colony forming unit, $\mathrm{cfu} / \mathrm{ml}$ ) were lower than those of tank water $\left(10^{3}-10^{5} \mathrm{cfu} / \mathrm{ml}\right)$. These counts remained relatively constant throughout the sampling period. Faecal coliforms appeared always in low numbers, $23 \mathrm{cfu} / \mathrm{ml}$ being the highest value recorded. On the other hand, counts of enterococci were low $\left(10^{1} \mathrm{cfu} / \mathrm{ml}\right)$ in inflowing water, but they increased to $10^{2}-10^{4}$ $\mathrm{cfu} / \mathrm{ml}$ in tank water.

\section{Generic Composition of Heterotrophic Bacteria}

The bacterial groups isolated from eel culture water and eels are listed in Tables 3 and 4. Pseudomonas was the most encountered genus. Furthermore, Vibrio sp., Micrococcus sp., Bacillus sp., and Flavobacterium sp. were usually recovered from all kinds of samples in low numbers (Table 3). Some differences between the bacterial microflora of eel culture water and eels were observed. Inflowing and tank waters showed the highest percentages of isolates of Moraxella and Acinetobacter, but the lowest ones of Aeromonas. In contrast, the highest percentages of isolates of Aeromonas, as well as the lowest ones of Moraxella 
Table 4. Generic distribution of the bacteria recovered from water and fish samples on TSA plates

\begin{tabular}{|c|c|c|c|c|}
\hline Bacteria & Inflowing water & Tank water & Elver & Silver eel \\
\hline Moraxella & $0^{*}$ & $12(8.2)$ & $1(0.5)$ & $1(0.8)$ \\
\hline Acinetobacter & $8(36.4)$ & $18(12.2)$ & $10 \quad(4.8)$ & $1(0.8)$ \\
\hline Pseudomonas & $5(22.7)$ & $78(53.0)$ & $77(37.2)$ & $66(54.1)$ \\
\hline Flavobacterium & $1 \quad(4.5)$ & $14(9.5)$ & 0 & $5(4.1)$ \\
\hline Janthinobacter & $1 \quad(4.5)$ & 0 & 0 & 0 \\
\hline Alteromonas & 0 & $1(0.7)$ & $3(1.4)$ & $4 \quad(3.3)$ \\
\hline Aeromonas & $1 \quad(4.5)$ & $6(4,1)$ & $67(32.4)$ & $14(11.5)$ \\
\hline Vibrio & $3(13.6)$ & $2(1.4)$ & $8(3.9)$ & $2(1.6)$ \\
\hline Plesiomonas & 0 & 0 & $1(0.5)$ & $1(0.8)$ \\
\hline Escherichia & 0 & 0 & $5(2.4)$ & $3(2.5)$ \\
\hline Enterobacter & 0 & 0 & $8 \quad(3.9)$ & $2(1.6)$ \\
\hline Serratia & 0 & 0 & $2(1.0)$ & 0 \\
\hline Citrobacter & 0 & 0 & $3(1.4)$ & 0 \\
\hline Staphylococcus & 0 & $2(1.4)$ & $3(1.4)$ & $9(7.4)$ \\
\hline Streptococcus & 0 & 0 & 0 & $6 \quad(5.0)$ \\
\hline Micrococcus & $2 \quad(9.1)$ & $9(6.1)$ & $17(8.3)$ & $7(5.7)$ \\
\hline Bacillus & $1 \quad(4.5)$ & $6(4.1)$ & $3(1.4)$ & $1(0.8)$ \\
\hline
\end{tabular}

* Number of isolates (relative frequencies).

Table 5. Species distribution in eel culture water (inflow and tank) and eel (elver and silver eel)

\begin{tabular}{lccc}
\hline \multicolumn{1}{c}{ Species } & Eel culture water & Healthy eel & Diseased eel \\
\hline P. fuorescens & $14(13.9)^{*}$ & $79(78.2)$ & $8(7.9)$ \\
$P$. putida & $31(56.4)$ & $24(43.6)$ & 0 \\
A. putrefaciens & $4(25.0)$ & $2(12.5)$ & $10(62.5)$ \\
A. hydrophila & $5(21.7)$ & $7(30.4)$ & $11(47.8)$ \\
A. sobria & $5(19.2)$ & $6(23.1)$ & $15(57.6)$ \\
A. caviae & $11(24.4)$ & $33(73.3)$ & $1(2.2)$ \\
V. anguillarum & $7(100)$ & 0 & 0 \\
$P$. shigelloides & 0 & $3(100)$ & 0 \\
\hline
\end{tabular}

* Number of isolates (relative frequencies).

and Acinetobacter were observed in elvers and silver eels (Table 4). Other genera such as Escherichia, Serratia, Citrobacter, Plesiomonas, and Streptococcus were only isolated from elvers and internal organs of silver eels (Tables 3 and 4).

Bacterial Species Recovered from Diseased European Eels and Its Serotyping

The population of elvers and silver eels suffered four epizootic outbreaks throughout the sampling period. In general, the outbreaks lasted 1-2 weeks, and the mortality reached nearly $80 \%$ of the eels stocked in each tank. Pathological signs such as petechial haemorrhages on the gill region and ventral side of the body, reddening of the fins, pale and haemorragic liver, and swollen kidney were observed in moribund eels. On January, pure cultures of Alteromonas putrefaciens were recovered from kidney and liver of silver eels during an outbreak of red fin disease. The diseased eels had been treated by the farmer with oxytetracyline, tetracycline, and trimethropim/sulphonamides before the sampling was made. Mixed cultures were usually isolated from diseased eels during the rest of epizootics (Table 3). However, the species A. hydrophila and A. sobria, as well as Alteromonas putrefaciens were encountered preponderant in diseased eel samples (Table 5). Other potential fish pathogens such as $P$. fluorescens, Vibrio anguillarum, and Plesiomonas shigelloides were mainly recovered from healthy eel or eel culture water (Table 5). Furthermore, the species $P$. putida and $A$. caviae were always recovered from the studied samples in absence of epizootics (Table 5).

None of the $P$. fluorescens isolates agglutinated with the antiserum made against the pathogenic reference strain O3L. Interestingly, most of the typable isolates of $A$. hydrophila from diseased eels (five out of eight isolates), as well as the reference strain $\mathrm{Y}-62$ pathogenic for Japanese eels, belonged to the 019 serogroup of Guinee 
and Jansen, ${ }^{10)}$ In contrast, isolates of $A$. hydrophila $\mathrm{O} 6$ and $\mathrm{O} 9$ were associated to healthy eels. The serotype $\mathrm{O} 24$ was mostly encountered among the typable isolates of $A$. sobria from all kinds of samples (seven out of sixteen isolates). Some $A$. sobria isolates from healthy and diseased eels belonged to the serotypes O4, O6, O11, O15, O16, and $\mathrm{O} 29$ of Guinée and Jansen. ${ }^{103}$ Our $V$. anguillarum isolates did not agglutinate with antisera $\mathrm{O} 1$ and $\mathrm{O} 2$ of Sorensen and Larsen. ${ }^{17}$ )

\section{Discussion}

The quality of eel culture water was found suitable for rearing eels with regard to its physicochemical parameters, which fell within those recorded by Gault. ${ }^{15)}$ However, temperature of tank water was always lower than $22-26^{\circ} \mathrm{C}$, optimal for the growth of Anguilla anguilla. ${ }^{18)}$ The values of biological oxygen demand in tank water were always higher than those in inflowing water, as a consequence of the organic contamination of the water caused by the intensive rearing. The amounts of viable heterotrophic bacteria in eel culture water (inflow and tank) maintained themselves within the limits described for unpolluted freshwater. ${ }^{19}$ ) As has been previously reported by Austin and Allen-Austin, ${ }^{20)}$ we have observed no variations of the bacterial population size related to water temperature increases. Faecal bacteria in eel culture water seemed to be introduced by diet since faecal coliform counts were always low and enterococci counts fluctuated from $10^{1}$ to $10^{4} \mathrm{cfu} / \mathrm{ml}$. The importance of foodborne enterococci contamination of water, as well as the incidence of streptococcicosis outbreaks in Japanese eels has been highlighted by Taniguchi. ${ }^{21)}$

Although the genus Pseudomanas was preponderant in all samples studied, we observed differences between the eels and the eel culture water with regard to their generic composition. Eel microflora was characterized by the high percentage of bacteria related to an intestinal habitat, such as Aeromonas, Plesiomonas, and enterobacteria which have been reported as saprophytic flora of the gastrointestinal tract of salmonids and warm-water fishes. ${ }^{12,28,23)}$ Eel culture water microflora was characterized by the low levels of bacterial genera of intestinal origin and also by the abundance of bacteria belonging to $\mathrm{Mo}$ raxella and Acinetobacter.

Opportunistic fish pathogens were isolated not only in the presence of epizootic outbreaks, but also in their absence. However, the species A. hydrophila, A. sobria, and A. putrefaciens were mainly associated with diseased eels. Alteromonas putrefaciens isolates were related to an infectious disease in silver eels treated with oxytetracycline, tetracycline, and trimethropim/sulphonamides in the farm. Until now this species has been associated with spoilage of fish fillets. ${ }^{24}$ but there are very few reports on its role as a member of the bacterial microflora of healthy and diseased living fishes. ${ }^{25)}$ Nevertheless when the virulence was evaluated by experimental infection of fingerlings (5-8 g), the isolates of $A$. hydrophila were revealed to be the most pathogenic ones for European eel, followed by those of $A$. sobria, whereas $A$. putrefaciens strains were avirulent for elvers (unpublished data). Isolates of other species described as fish pathogens such as Vibrio anguillarum ${ }^{28)}$ and Plesiomonas shigelloides ${ }^{277}$ were always recovered from eel culture water or healthy eels. Furthermore, we observed that the species $P$. fluorescens, $P$. putida, and $A$. caviae were mainly recovered from the studied samples in the absence of epizootics.

Following the typing scheme of Guinée and Jansen ${ }^{103}$ we have observed that serotype O24 was preponderant in $A$. sobria isolates, but no relationship between origin and serogroup was observed for this species. The isolates of $A$. hydrophila 019 were always recovered from eels and tank water during epizootic outbreaks. Interestingly, the Spanish isolates of $A$. hydrophila associated with diseased Anguilla anguilla, as well as the Japanese strain Y-62 pathogenic for Anguilla japonica belonged to the 019 serogroup.

Further studies are in progress to investigate the relationship between pathogenicity and serotype of these $A$. hydrophila strains, as well as the possible importance of the latter as an epidemiological marker.

\section{Acknowledgements}

C. Esteve was supported by a grant from the Ministerio de Educación y Ciencia, Spain. We thank $R$. Ruano for allowing us to take the samples, J. M. Soria for assistance in chemical analysis, Y. Santos, T. P. Nieto, and A.E. Toranzo for giving the antisera and A. J. Velázquez de Castro for critical reading of the manuscript. This work has been partially supported by the University of Valencia (Spain). 


\section{References}

1) K. Muroga, Y. Jo, and M. Nishibuchi: Fish Pathol. 12, 141-145 (1976).

2) H. Wakabayashi and S. Egusa: Nippon Suisan Gakkaishi, 38, 577-587 (1972).

3) T. Nakai and K. Muroga: Fish Pathol, 17, 147150 (1982).

4) E. G. Biosca, C. Amaro, C. Esteve, E. Alcaide, and E. Garay: J. Fish Dis., 14, 103-109 (1991).

5) G. H. Kou: Aquaculture, 2, 22-33 (1972).

6) W. L. Rickards: in "A diagnostic manual of eel diseases occurring under culture conditions in Japan," Sea Grant Publication, North Carolina, 1978, pp. 1-6.

7) N. Levanon, B. Motro, D. Levanon, and G. Degani: Bamidgeh, 38, 55-63 (1986).

8) S. Mellergaard and I. Dalsgaard: Aquaculture, 67, 139-146 (1987).

9) D. Leblanc, K. R. Mittal, G. Oliver, and R. Lallier: Appl. Environ. Microbiol, 42, 56-60 (1981).

10) P. A. M. Guinée and W. H. Jansen: Zbl. Bakt. Hyg. A, 265, 305-313 (1987).

11) J. D. Humphrey, C. E. Lancaster, N. Gudkovs, and J. W. Copland: J. Fish Dis., 10, 403-410 (1987).

12) M. M. Cahill: Microb. Ecol., 19, 21-41 (1990).

13) A. E. Greenberg, R. Rhodes-Trussel, and L. S. Clesceri: "Standard Methods for the Examination of Water and Wastewater". American Public Health Association, Inc., Washington, 1985.

14) M. Poppof: in "Bergey's Manual of Systematic Bacteriology" (ed. by N. R. Krieg \& J. G. Holt), Vol. 1, Williams \& Wilkins, Baltimore, 1984, pp. 545-548.

15) J. V. Lee and T. J. Donovan: in "Isolation and identification of micro-organisms of medical and veterinary importance," (ed. by C. H. Collins \& J. M. Grange), Academic Press, London, 1985, pp. 13-33.

16) N. J. Palleroni: in "Bergey's Manual of Systematic Bacteriology" (ed. by N. R. Krieg \& J. G. Holt), Vol. 1, Williams \& Wilkins, Baltimore, 1984, pp. 141-199.

17) U. B.S. Sorensen and J. L. Larsen: Appl. Environ. Microbiol., 51, 593-597.

18) J. Gault: in "Aquaculture, Vol. 2" (ed. by G. Barnabé), Technique et Documentation (Lavoisier), Paris, 1986, pp. 742-771.

19) E. E. Geldreich: J. Water Pollut. Con. Fed., 69, 1222-1244 (1977).

20) B. Austin and D. Allen-Austin: J. Appl. Bacteriol. Symposium Supplement, 2075-2265 (1985).

21) M. Taniguchi: Nippon Suisan Gakkaishi, 48, 1721-1723 (1982).

22) M. Yoshimizu, T. Kimura, and M. Sakai: Nippon Suisan Gakkaishi, 42, 9l-99 (1976).

23) J. Vandepitte, L. VanDamme, Y. Fofana, and J. Desmyter: Bull. Soc. Pathol. Exotique, 73, 139-149 (1980).

24) N. C. Gillespie: J. Appl. Bacteriol, 50, 29-44 (1981).

25) M. O. Saeed, M. M. Almoudi, and A. H. AlHarbi: Dis. Aqua. Org., 3, 177-180 (1987).

26) O. Nybelyn: Med. Untersäkn. Anst. Stovattensfisk. Stoch., 8, 1-62 (1952).

27) J. M. Cruz, A. Saraiva, J. C. Eiras, R. Branco, and J. C. Sousa: Bull. Eur. Assoc. Fish. Pathol., 6, 20-22 (1986). 